\title{
Correction to: Public Reason in a Pandemic: John Rawls on Truth in the Age of COVID-19
}

\section{Calvin H. Warner ${ }^{1}$}

Published online: 2 March 2022

(C) The Author(s), under exclusive licence to Springer Nature B.V. 2022

\section{Correction to: Philosophia}

https://doi.org/10.1007/s11406-021-00459-8

The original version of the article unfortunately contained mistakes.

The text "I'd also like to add a footnote to the efect of "I'm grateful to Jared Riggs and Robert Talisse for thorough feedback on this paper, as well as Reviewer whose comments and questions greatly improved the argument." under the Introduction section should be removed and the footnote "I'm grateful to Jared Riggs and Robert Talisse for thorough feedback on this paper, as well as Reviewer whose comments and questions greatly improved the argument." should be added in this paper.

The original article has been corrected.

Publisher's Note Springer Nature remains neutral with regard to jurisdictional claims in published maps and institutional affiliations.

The original article can be found online at https://doi.org/10.1007/s11406-021-00459-8.

Calvin H. Warner

calvin.h.warner@vanderbilt.edu

1 Vanderbilt University, Nashville, TN 37235, USA 